Portland State University

PDXScholar

6-16-2021

Romans, Religion, and the Aid of the Gods: An Exploration of the Pontifex Maximus in Roman Society

Gregory Meade

Portland State University

Follow this and additional works at: https://pdxscholar.library.pdx.edu/honorstheses

Part of the Ancient History, Greek and Roman through Late Antiquity Commons Let us know how access to this document benefits you.

Recommended Citation

Meade, Gregory, "Romans, Religion, and the Aid of the Gods: An Exploration of the Pontifex Maximus in Roman Society" (2021). University Honors Theses. Paper 1035.

https://doi.org/10.15760/honors.1061

This Thesis is brought to you for free and open access. It has been accepted for inclusion in University Honors Theses by an authorized administrator of PDXScholar. Please contact us if we can make this document more accessible: pdxscholar@pdx.edu. 


\begin{abstract}
Ancient Roman history is heavily defined by an evolving relationship with Romans and their gods. Between the Monarchy (753 BCE - 509 BCE) and Republic (509 BCE - 27 BCE), religion developed into an interconnecting web of institutions that performed rituals to ensure appeasement of the gods in various Roman affairs. Fostering a productive relationship with the gods equated to what the Romans called maintaining pax deorum or peace with the gods. This thesis explores the moments in which the influence of religion played a key role in the developing periods of the Monarchy and Republic leading up to the close of the Second Punic War (218 BCE - 201 BCE). Traditionally, modern scholars have acknowledged religion to have played an elemental role in Roman affairs. This thesis further expands upon previous research to revisit how the historical accounts of Livy, Plutarch, and Polybius portrayed religion's role in society. The primary focus of analysis will examine the role and depiction of the lives and careers of the men who held the title of head priest known as the pontifex maximus. What is found is that the qualifications and character demanded of the pontifex maximus did not fit any one mold. Initially, the responsibilities of the pontifex maximus related to maintaining an adherence to proper religious ritual in the affairs of the Roman community. As Roman territory expanded by means of conquest and war, the role of the pontifex maximus began to expand and integrate into military affairs. This thesis further explores the evolution of the definition of pax deorum in the eyes of the Romans. Romans utilized ritual to honor the gods, which they perceived to be a key factor in the pursuit of prominence and glory. As they sought to obtain these objectives, Romans transitioned from soliciting the approval of the gods to requesting active intervention.
\end{abstract}




\title{
Romans, Religion, and the Aid of the Gods: An Exploration of the Pontifex Maximus In Roman Society
}

\author{
by \\ Gregory W. Meade \\ An undergraduate thesis submitted in partial fulfillment of the \\ requirements for the degree of \\ Bachelor of Science \\ In \\ University Honors \\ and
}

Social Science

Thesis Advisor

Dr. Brian Turner

Portland State University 


\section{Acknowledgements}

I would like to express my sincere gratitude to my advisor Dr. Brian Turner. Thank you for your dedicated time and exposure to the intricacies of quality research and writing. You displayed unwavering patience and support as you reviewed and later discussed each draft and writing sample I submitted over the course of this process. I attribute much of my growing passion for ancient Roman and Greek history to your extensive knowledge and presentation methodology. To my wife Anna, words cannot express enough the appreciation I have for the sacrifices you've made to support my academic pursuits. Thank you for allowing me to run my thoughts by you and responding with thoughtful and useful advice. I would also like to thank the rest of my family for their endless support in enabling me to dedicate myself to such a fulfilling undertaking. 


\section{TABLE OF CONTENTS}

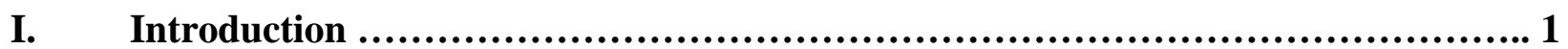

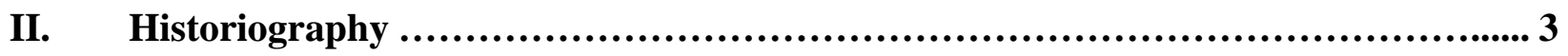

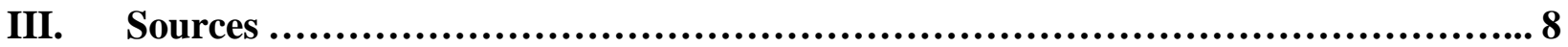

IV. The Progression of the Pontifex Maximus in Roman Religion ........................ 14

a. The Regal Period $(753-509$ BCE) .......................................................... 14

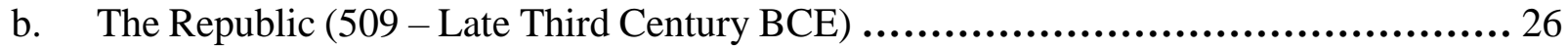

c. The Second Punic War $(218$ - 202 BCE) .................................................. 39

V. Conclusion .............................................................................. 44

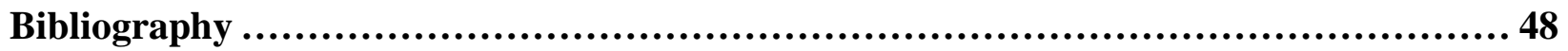




\section{Introduction}

In $340 \mathrm{BCE}$, the Romans were in the midst of a battle with the Latins at the base of Mount Vesuvius. ${ }^{1}$ According to Livy, the Latins were gaining the upper hand and a disillusioned Roman army was facing certain defeat. ${ }^{2}$ Decius, a consul and general looking to the gods for aid, shouted at one of his fellow Romans: "Valerius, we need the help of the gods! Let the pontifex maximus dictate to me the words in which I am to devote myself for the legions." ${ }^{3}$ Marcus Valerius, the pontifex maximus (high priest of Rome), instructed Decius on the necessary ritual what the Romans called devotio. The words Decius recited sought aid and good favor from the gods in exchange for his forthcoming self-sacrifice. ${ }^{4}$ Reciting these words, Decius charged alone into the middle of the Latin forces. Livy described the astonishment of both the Romans and Latins as they witnessed the spectacle:

[Decius] appeared something awful and superhuman, as though sent from heaven to expiate and appease all the anger of the gods and to avert destruction from his people and bring it on their enemies. ${ }^{5}$

Although Decius would die, the Romans would emerge victorious in this battle.

The scene depicted above illustrates just how much stock a Roman placed in the agency of the gods to determine the outcome of any given situation. Romans held their gods in high esteem and Roman history was heavily defined by the influence of the gods. This thesis discusses how the Romans viewed this relationship with the gods and the direct connection between religion and sociopolitical affairs through an examination of the pontifex maximus. After first examining the development of religious institutions during the Roman monarchy (753-

\footnotetext{
${ }^{1}$ Livy 8.4-8.

${ }^{2}$ Livy 8.9 .

${ }^{3}$ Livy 8.9.

${ }^{4}$ Livy 8.9 .

${ }^{5}$ Livy 8.9.
} 
$509 \mathrm{BCE})$, the thesis considers the role of the pontifex maximus from the foundation of the Republic (in 509 BCE) through the end of the Second Punic War (c. 200 BCE).

The formative years of the Roman monarchy established several religious institutions which continued to expand and develop well into the Republican period. ${ }^{6}$ Before analyzing these specific events, the thesis begins with a survey of scholarly opinions about the connection between Roman religion and religious offices in Rome's early history. There follows brief biographies of the main sources: Livy, Plutarch, and Polybius, with specific attention paid to the historical context and influences in which they wrote. This thesis then pinpoints key moments which elevated and evolved the significance of the pontifex maximus. An analysis of the lives, careers, and actions of those who held the position of pontifex maximus in the above-mentioned sources illustrates those moments. The position changed to align with contemporary priorities during the Republic's rise to prominence, including the progressive drive by the Roman public to seek greater agency in the election to the position. Consequently, a fresh perspective on how Romans employed religious offices like the pontifex maximus in the development of political, military, and social aspects of the Republic will emerge.

\footnotetext{
${ }^{6}$ Mary Beard, James North, Simon Price, Religions of Rome: Volume I. A History (New York: Cambridge University Press, 2013), 1-18.
} 


\section{Historiography}

Plutarch, whose life and writings are discussed further below, asserted that the pontifex maximus was initially responsible for "interpreting the divine will," which meant he oversaw public and private ceremonial rituals and educated his subordinates - the pontifices and the three flamines - on proper worship and tribute to the gods. ${ }^{7}$ The pontifices were recognized for their spiritual auctoritas (authority), making them the experts of sacred law and ritual. ${ }^{8}$ The flamines were three priests solely dedicated to the gods Jupiter, Mars, and Quirinus. ${ }^{9}$ The responsibilities of all these individuals equated to maintaining the pax deorum, or the peace of the gods, a foundational value held by Romans. ${ }^{10}$ Satterfield analyzed Livy's use of pax deorum and concluded that he utilized the term "as an explanation for disaster or success" in reference to particular events in Roman history. ${ }^{11}$

Religion served as a means to unify the public of Rome. Maintaining the pax deorum brought peace of mind to the Roman communities. In separate works, Rives as well as Beard, North, and Price have established that religion played an integral role in how political decisions were justified and accepted among the Roman public. ${ }^{12}$ Such conclusions raise the question of the extent to which the defense of the pax deorum was a means of political manipulation rather

\footnotetext{
${ }^{7}$ Plut. Numa 9.4. Abbreviations of primary sources follow the Oxford Classical Dictionary.

${ }^{8}$ Beard et. al, Religions of Rome, 24.

${ }^{9}$ Beard et. al, Religions of Rome, 1.

${ }^{10}$ David M. Gwynn, The Roman Republic: A Very Short Introduction (Oxford, UK: Oxford University Press, 2012), 43; Eric M. Orlin, Temples, Religion, and Politics in the Roman Republic (Leiden: Brill, 2002), 4. Pax deorum is a Latin term which is interchangeable with pax deum. The definition can be broken down as pax which means "peace" and deum or deorum which are both genitive plural forms of deus meaning "deity" or "god". Maintaining pax deorum meant maintaining good favor among Roman gods. Romans attributed success and failure as it pertained to various sociopolitical, economic and military concerns to have been heavily influenced by the will of the gods.

${ }^{11}$ Susan Satterfield, "Livy and the Pax Deum," Classical Philology 111, no. 2 (April 2016): 174

${ }^{12}$ James Rives, Religion in the Roman Empire (Malden, MA: Blackwell Publishing, 2007); Beard et. al, Religions of Rome.
} 
than genuine belief. ${ }^{13}$ Referring to the Middle Republic, Champion posed a vital question that may be asked of any time period, including the present:

Did elites $[\ldots]$ believe in their gods, in the sense that they actually accepted as a point of fact that there were supernatural forces 'out there,' with whom they must negotiate in order to influence the course of events in their favor in the mundane world ${ }^{14}$

This modern scholar echoes Polybius, who argued that religion was structurally designed to steer Roman citizens toward conformity. ${ }^{15}$ Champion observed that sociopolitical decisions were often publicly justified by men who held elite religious titles and who claimed to be executing the will of the gods. ${ }^{16}$

While there is a tendency to assume a wholly political practice, there is still room for interpretation. A Roman's definition of maintaining the pax deorum evolved throughout the time of the Republic. During periods of internal political developments, maintaining the pax deorum meant fostering a positive relationship with gods. ${ }^{17}$ The Roman elite used gods as sacred consultants to help guide policy and obtain public acceptance for decisions made by the senate and consuls. ${ }^{18}$ While at war, the gods were viewed as agents who controlled whether the Romans won or lost. ${ }^{19}$ Therefore, it was even more imperative to maintain the pax deorum during a war campaign as the stakes were high and felt on a more immediate scale.

Roman religious rituals and traditions were not exactly uniform. A Roman identified with a specific religious cult, and within that cult, often the social and economic status of an

\footnotetext{
${ }^{13}$ Gwynn, Roman Republic, 43.

${ }^{14}$ Craig B. Champion, The Peace of the Gods: Elite Religious Practices in the Middle Roman Republic (New Jersey: Princeton University Press, 2017), 6.

15 Polyb. 6.56.6-7.

${ }^{16}$ Champion, Peace of the Gods, 6.

${ }^{17}$ Gwynn, Roman Republic, 41-5.

${ }^{18}$ Gwynn, Roman Republics, 45.

${ }^{19}$ Beard et. al, Religions of Rome, 74.
} 
individual correlated with their level of direct involvement. ${ }^{20}$ Rives argues that religious piety served to unite societies and, at times, to manipulate buy-in to the actions of the central government. $^{21}$

Scholars have noted that the level of prestige which accompanied the title of pontifex maximus made it an attractive role to acquire for someone who desired to advance their political career toward a position of high authority such as consul, praetor or dictator. ${ }^{22}$ The process by which the pontifex maximus was elected developed over time. Plutarch described how (initially) the pontifex maximus was appointed by the king. ${ }^{23}$ During the early republic, the pontifex was chosen by an elder pontiff or group of pontifices. By third century BCE, a man had to first acquire the title of pontiff prior to becoming eligible and was then elected by the Roman public. ${ }^{24}$ The development of a public election suggests how high a value was placed on the position of pontifex maximus in the eyes of Romans.

Both the ancient Romans and our later sources identified specific qualities that propelled an individual's rise to the top of the nobility. The first and foremost was to have dignitas, which Gwynn described as "the sum of an individual's personal worth and the worth of his family," which can be interpreted as the socioeconomic status of an individual. ${ }^{25}$ Dignitas was directly linked to an individual's political potential within the Republic. Enhancing one's dignitas required a second quality, gloria, which sounds much like its English translation, glory, and typically was obtained through leading a victorious

\footnotetext{
${ }^{20}$ Rives, Religion in Roman, 106-8. Rives viewed religious traditions as common practice amongst Romans. However, he proposed that the specific traditions could vary drastically from one cult and another.

${ }^{21}$ Rives, Religion in Rome, 106-7.

${ }^{22}$ Beard et. al, Religions of Rome, 100.

${ }^{23}$ Plut. Numa 9.1-4.

${ }^{24}$ Beard et. al, Religions of Rome, 19.

${ }^{25}$ Gwynn, Roman Republic, 29.
} 
war campaign. ${ }^{26}$ As we will see, the pontifex maximus also began to display these qualities as the Republic progressed.

Looking back to the foundations of Roman religion, accounts of the Roman Monarchy are primarily based on tales told by historians who lived centuries later. Archeological evidence certainly aids in the validation of these accounts, however written sources found to exist prior to the founding of the Roman Republic are scarce. ${ }^{27}$ Additionally, much of the early Republican accounts were written long after these events took place, which requires much speculation when seeking to determine fact from lore. It is not surprising that religion might suddenly play a more prominent role in the accounts of Rome's foundational history, given the vague and unreliable record-keeping available at the time. Acceptance of religion requires an element of blind faith. Therefore, our sources' incorporation of religion into their descriptions of the past mitigated the desire to question the details. Harriet Flower rationalized how oral historical "information can be preserved reliably over a span of about three generations, but then becomes scarcer and less detailed once a society contemplates times that are beyond living memory." 28 Unpreserved documented history tends to morph into a form of mythology or a manicured version that enables a society to reconcile the past.

It is important to consider how early accounts of the Roman Monarchy, written centuries after Rome's founding, can only be based on assumptions and a motivation to tell a story contoured to the sociopolitical affairs of the time period during which these texts were made public. Fay Glinister utilized Livy as a major source for her analysis on the transition period

\footnotetext{
${ }^{26}$ Gwynn, Roman Republic, 29.

${ }^{27}$ Gwynn, Roman Republic, 7.

${ }^{28}$ Harriet Flower, Roman Republics (New Jersey: Princeton University Press, 2010), 38.
} 
between the Roman Monarchy and Republic. Glinister remarked on the challenge of reviewing ancient sources that can only be validated to a certain point. ${ }^{29}$ Contemporary concerns surely influenced the stories our sources told.

J. E. Lendon advocated for recognition that ancient historians took liberties in embellishing or fabricating tales to assemble their narratives. ${ }^{30}$ However, he did not believe that this fact should devalue these accounts, and maintained a firm belief that ancient authors "tried in their narratives to tell the truth as they understood it." This perspective allows a modern historian to extract the context of how Romans accepted and considered their history from their texts. ${ }^{31}$ The best way to utilize these sources is to understand that these accounts still have value for explaining how Romans got from point A to point B. There were enough collectively recognized major events to provide a basic road map for informing Romans of their history, even if it was an accepted practice for ancient historians to include compelling details to keep the reader engaged. Despite some fantastical elements, our sources - to which we turn next - still offer genuine explanations for Rome's expanding power and the progressive role of the pontifex maximus.

\footnotetext{
${ }^{29}$ Fay Glinister, "Politics, Power, and the Divine: The Rex Sacrorum and the Transition from Monarchy to Republic at Rome" Antichthon: Journal of the Australian Society for Classical Studies; Adelaide, Vol. 51 (2017), 71.

${ }^{30}$ J. E. Lendon, "Historians without history: Against Roman historiography" The Cambridge Companion to the Roman Historians, ed. Andrew Feldherr (Cambridge: Cambridge University Press, 2009), 43.

${ }^{31}$ Lendon, "Historians without history," 42-3. Much of Lendon's conclusion came from Cornell's argument that the main events told in these accounts have been "confirmed by archeology."
} 


\section{Sources}

This thesis examines three principal sources: Livy, Plutarch, and Polybius. Titus Livius (or Livy) was a Roman historian who lived between 59 BCE and $17 \mathrm{CE}$. He grew up in Patavium, a city within the province of Cisalpine Gaul, known for its wealth and nobility. ${ }^{32}$ Livy dedicated the bulk of his adult life to studying and writing Roman history. His most notable work, Ab Urbe Condita (From the Foundation of the City), totaled 142 books, most of which remain undiscovered. ${ }^{33}$ This work began with Rome's founding in 753 BCE and culminated in 9 BCE.

Livy was a child during the final years of the first triumvirate, the time period of Caesar. He was a young man during the second triumvirate, which culminated in the end of the Republic and the emergence of Rome's first emperor, Augustus. ${ }^{34}$ The political tone of the period in which Livy grew up left a lasting impression. He is not recognized as a soldier, nor is it believed that he held any position within the Roman government, yet he was known to have been a strong supporter of senatorial governorship. ${ }^{35} \mathrm{He}$ displayed a desire to portray moments of progression as the Republic formed. These convictions contextualize Livy's sometimes chaotic and disorganized characterizations of the early Roman monarchy and somewhat romanticized image of the Republic's early years.

Livy depicted the desire for the plebeians to obtain more representation, which included obtaining eligibility to be considered for religious offices. He clearly viewed religion as part of a progressive path in politics. ${ }^{36} \mathrm{P}$. G. Walsh claims that "it stands beyond doubt that Livy had

\footnotetext{
${ }^{32}$ T. J. Luce, Livy: The Rise of Rome. Books 1-5 (Oxford: Oxford World Classics, 2009), ix.

${ }^{33}$ Luce, Livy, xi.

${ }^{34}$ Luce, Livy, ix.

${ }^{35}$ Luce, Livy, x-xi.

${ }^{36}$ R. M. Ogilvie, A Commentary on Livy: Books 1-5 (Oxford: Oxford University Press, 1984), 293.
} 
unshakable belief in the old gods. ${ }^{37}$ Perhaps Livy's political convictions were bound by the foundations of religion and influenced his portrayal of the Roman nobles responsible for founding the Republic.

Livy's accounts of the development of the Roman Republic are written in a tone that demonstrates the ethical and honorable values he projected onto the founding members of the Republic. He chronicled the political and social events of the time in great detail. Livy was an acquaintance (and possibly viewed as a friend) of the first Roman emperor, Augustus. Though they may not have shared the same values, historical accounts infer that there was a mutual respect between the two men. ${ }^{38}$ However, this did not cause Livy to refrain from speaking his mind. It is rumored that he boasted of his admiration for men like Brutus and Pompey. ${ }^{39}$ Admiration for such men and their qualities alludes to Livy's choice to align himself with Rome's traditional values, especially placing high value on religious ritual and a collaborative form of authority.

A second major source, Plutarch's biographies, offer an opportunity for comparative analysis. Lucius Mestrius Plutarchus (Plutarch) was a Second Sophistic biographer and philosopher who was born c. $45 \mathrm{CE}$ and died sometime after $120 \mathrm{CE} .{ }^{40}$ Plutarch was born and lived most of his life in Chaeronea, Greece. He was appointed to a variety of semi-trivial political positions, yet dedicated most of his civil service to being a member of the priesthood at Delphi. ${ }^{41}$ Being of Greek decent, he was later made a Roman citizen and is said to have been favored by the emperors Hadrian and Trajan. ${ }^{42}$

\footnotetext{
${ }^{37}$ P.G. Walsh, Livy: His Historical Aims \& Methods (Bristol: Bristol Classical Press, 1989), 46.

${ }^{38}$ Walsh, Livy, 10-11.

${ }^{39}$ Oxford Classical Dictionary ( $4^{\text {th }}$ ed.), (hereafter $O C D$ ), s.v. "Livy (Titus Livius)".

${ }^{40}$ The Oxford Encyclopedia of Ancient Greece and Rome (hereafter OEAGR), s.v. "Plutarch". For more on Second Sophistic see Brill's New Pauly (hereafter BNP) s.v. "Second Sophistic".

${ }^{41}$ OEAGR, s.v. "Plutarch".

42 OEAGR, s.v. "Plutarch".
} 
Plutarch immersed himself in the biographical studies of numerous ancient historic figures, most of which derived from Greek and Roman decent. He wrote a series of paired biographies entitled Parallel Lives, which depicted the lives of notable figures from Greek and Roman history. ${ }^{43}$ There are twenty-three surviving pairs of these biographies in existence. The Oxford Encyclopedia of Ancient Egypt described a collection of other works, Moral Essays, in which Plutarch tackled subjects such as "greed, flattery, loquacity, superstition, education, and marriage." ${ }^{44}$ In these essays, Plutarch attempted to characterize the humanity, vulnerability, and mentality of those living in ancient times in order to draw out their motivations for decisions that shaped Greco-Roman society in the time period that he lived.

Having spent a third of his life as a priest, Plutarch developed a compulsive interest in religious history. The French philosopher Jean Hani considered Plutarch to be one of "antiquities best historian of religions." ${ }^{\prime 4}$ Plutarch covered the lives of several notable historical figures, such as Julius Caesar and Fabius Maximus. He not only articulates their military and political careers, but also emphasizes that their authority could be partially attributed to their religious positions. He aligns great men with their membership to religious office, further perpetuating a belief that positions like the pontifex maximus held influence and relevance.

Plutarch's history is written in a far less romanticized tone than Livy. Although living under Roman rule, Plutarch does not seem to have expressed much discontent. He does display an element of Greek pride, evidenced by his desire to celebrate the lives and accomplishments of

\footnotetext{
${ }^{43}$ OEAGR, s.v. "Plutarch".

${ }^{44}$ The Oxford Encyclopedia of Ancient Egypt (hereafter OEAE), s.v. "Plutarch".

${ }^{45}$ OEAE, s.v. "Plutarch".
} 
individuals in Greek history. This can be seen in his efforts to intertwine the ancient Greeks with the Romans, a technique not uncommon among Second Sophistic Greek authors. ${ }^{46}$

A third ancient historian, Polybius, offers an outsider's perspective on Rome's adherence to religion and the power of religious positions. Polybius was born ca. 202 BCE in Megalopolis, a city located in southern Greece. ${ }^{47}$ The Roman army forcibly relocated him to Rome after his military involvement in a rebellion against Roman control in $168 \mathrm{BCE} .{ }^{48}$ Polybius would remain in Rome for well over a decade and chose to redirect his ambitions to establishing himself as a scholar. Polybius' extensive knowledge of Greek culture, philosophy, and politics captured the attention of many members of the Roman elite. ${ }^{49}$

His developing reputation brought Polybius to the inner circle of Scipio Aemilianus, a renowned general, who admired his intellect and passion for Roman history. Mellor posited that it was “under Scipio's patronage [... that] Polybius was able to travel throughout Italy, as well as gain access to private libraries and archives in Rome." ${ }^{50}$ Polybius wrote forty books chronicling Rome's remarkable accomplishments of imperial expansion between 220 and 144 BCE. ${ }^{51}$ Of these forty books, only five have survived in their entirety, while all that remains of the remaining books are fragments of text. ${ }^{52}$

Polybius adhered to a strict methodology when it came to the study of history. He felt that a historian had the responsibility to track down and scrutinize original evidence found in

\footnotetext{
${ }^{46}$ Tim Whitmarsh, Beyond the Second Sophistic: Adventures in Greek Post-Classicism (Berkeley: University of California Press, 2018), 138-9.

${ }^{47}$ Ronald Mellor, The Historians of Ancient Rome: An Anthology of the Major Writings. $3^{\text {rd }}$ ed. (New York: Routledge, 2013), 10.

${ }^{48}$ Mellor, Ancient Rome, 10. The Achaean League, led by Polybius's father Lycortas, was a militarized group of Greek city-states who sought independence from the Roman Empire.

${ }^{49}$ OEAE, s.v. "Polybius".

${ }^{50}$ Mellor, Ancient Rome, 10.

${ }^{51}$ Mellor, Ancient Rome, 11.

${ }^{52}$ Mellor, Ancient Rome, 11.
} 
archives to better interpret the works of earlier historians. Polybius believed that obtaining extensive geographic awareness of an area of study was crucial in deciphering the motivations, triumphs, and perils of any major event. Additionally, he asserted that having direct involvement in administrative affairs brought valued insight and accuracy to historical accounts. Unlike Livy or Plutarch, this "pragmatic" approach to history caused Polybius to limit the scope of his study to a time period that he had lived through or which was recent enough for there to have been adequate surviving evidence. ${ }^{53}$

Polybius refrained from publishing a history that pandered to the wants of a reader seeking an epic novel. In contrast to Polybius, Livy wrote not only to inform but also to entertain his reader with the drama of a storyline. Polybius wrote in extensive detail and transitioned between regions to provide an account of simultaneous events and their significance. Throughout his work, he would interject a periodic historiography to inform readers of his process and defend his intentions. ${ }^{54}$

Polybius did not portray himself as having been personally influenced by religion, and his lack of religious interest played a significant role in how he framed the context of events. He refrained from incorporating the actions of Roman religious leaders into his accounts. As stated previously, Polybius saw Roman religion as a construct purposed to govern people and maintain order. In Book 6, Polybius makes the following statement about Roman religion:

But the quality in which the Roman commonwealth is most distinctly superior is in my opinion the nature of their religious convictions. I believe that it is the very thing which among other peoples is an object of reproach, I mean superstition, which maintains the cohesion of the Roman State. ${ }^{55}$

\footnotetext{
${ }^{53}$ For Polybius' proclaimed requirements of a historian, see Mellor, Ancient Rome, 11, and $O C D$, "Polybius." ${ }^{54}$ see Polybius, 8.1-2, 9-10.

55 Polyb.6.56.6-7.
} 
Here, Polybius is making the claim that the Romans were indoctrinated with religion as a means to gain acceptance for the dominant form of government. Traditions of tribute and piety may correlate to an acceptance of unified laws and sociopolitical process. Polybius contended that in part it was the fear of the gods that kept Romans honest. ${ }^{56}$ Beard, North and Price assert that Polybius can be considered the first "contemporary observer" to evaluate Roman religion. ${ }^{57}$ These scholars proposed that Polybius saw religion "as a means by which the ruling elite manipulated and disciplined their people." ${ }^{58}$ At times, Polybius may have even been present to witness the execution and impact of religious influence in Roman politics, even if he chose not to emphasize it in his account. While Polybius did not cover most of the events addressed in this thesis, utilizing him grounds any embellishment in the accounts of Livy and Plutarch. Polybius' view of the Roman's use of religion to control the masses will be a notion strongly considered as we advance through the time periods of the monarchy and early Republic. The interconnection between religion and politics can be seen in the analysis of the following narratives of those in the role of the pontifex maximus.

\footnotetext{
${ }^{56}$ Polyb. 6.56.

${ }^{57}$ Beard et. al, Religions of Rome, 108.

${ }^{58}$ Beard et. al, Religions of Rome, 108.
} 


\section{The Progression of the Pontifex Maximus in Roman Religion}

\section{a. The Regal Period (753 - 509 BCE)}

The regal period of Rome traditionally began with Romulus' founding and ruling of Rome in $753 \mathrm{BCE}$ and concluded when a group of Roman elites usurped power from the seventh and final king, Tarquinius Superbus, in 509 BCE. ${ }^{59}$ Scholars such as Cornell question the likelihood that a span of nearly 250 years would have been limited to only seven kings. ${ }^{60} \mathrm{He}$ proposed that conventional history may have only mentioned a king as a means to have a figurehead assigned to notable events during the regal period. ${ }^{61}$ Ogilvie (who wrote a commentary on Livy's books) indicated how kings were "singled out for some one particular quality: Romulus for military expertise, Numa for the creation of the religious observances of peacetime, Tullus for ferocity, Ancus for the ceremonies of war." ${ }^{\text {"2 }}$ For the purpose of an analysis of religion's development, the actions and events during the reign of Romulus, Numa, and Ancus will be reviewed here.

Livy's origin story of Rome's founding by Romulus in 753 BCE emphasized how the first king's actions and public following derived from various interpretations of signs presented by the gods. ${ }^{63}$ Romulus and his twin brother Remus tied their right to the founding and name of what would become Rome to the augural "signs of heaven's will” which entailed an interpretation of the flight pattern of birds over designated sacred locations assigned to each brother. ${ }^{64}$ Augurs, reputed for their interpretation of the sacred significance of environmental

\footnotetext{
${ }^{59}$ T. J. Cornell, The Beginnings of Rome: Italy and Rome from the Bronze Age to the Punic Wars (c. 1000-264 BC), (New York: Routledge, 1995), 119-20; Livy 1.7-60

${ }^{60}$ Cornell, Beginnings of Rome, 119.

${ }^{61}$ Cornell, Beginnings of Rome, 119-21.

${ }^{62}$ Ogilvie, Livy, 31.

${ }^{63}$ Livy 1.6-7.

${ }^{64}$ Livy 1.6-7.
} 
interactions, were the first known established priests (or some form of spiritual interpreter) and already had a presence prior to Rome's founding. ${ }^{65}$ Both Romulus and Remus claimed a spiritual right to rule based on the augury, resulting in conflict between the brothers and their supporters. Ultimately, Romulus emerged the victor in the aftermath of the death of his brother. ${ }^{66}$ Livy admitted that much of his foundational history of Rome was loosely based on historical accounts whose gaps were filled with embellishment to make the story more interesting or palatable. ${ }^{67}$ So, the specific circumstances of Remus' death are muddled by multiple versions of events, each detailing some form of dramatic engagement that left Romulus as the sole king of Rome.

Romulus was traditionally believed to have ruled Rome for approximately 37 years. ${ }^{68}$ During that time, he expanded Rome's power and population, which was not as homogenous as one might think. The early establishments of religion thus became a source for some semblance of unification. Romulus is recognized as having solidified the first designated gods such as Janus, Jupiter, and Mars. ${ }^{69}$ As Romulus sought to increase the population of Rome further, he resorted to instructing his army to rape the neighboring woman of the Sabines. ${ }^{70}$ War ensued as a result, eventually concluding in a treaty that established the short-lived co-reign of Romulus and the Sabine leader Titus Tatius. ${ }^{71}$ Tatius contributed to Roman religion by establishing additional gods such as Saturn and Luna. ${ }^{72}$

Plutarch remarked on the mysterious disappearance of Romulus during a public sacrifice, which suddenly left Rome without a clear successor. Rome underwent a period of civil strife as

\footnotetext{
${ }^{65}$ Beard, et. al, Religions of Rome, 21-22.

${ }^{66}$ Livy 1.7.

${ }^{67}$ Livy 1. Preface.

${ }^{68}$ Plut. Numa 2.1.

${ }^{69}$ Duncan Macrae, Legible Religion: Books, Gods, and Rituals in Roman Culture (Cambridge: Harvard University Press, 2016), 31.

${ }^{70}$ Cornell, Beginnings of Rome, 58.

${ }^{71}$ Cornell, Beginnings of Rome, 58.

${ }^{72}$ Macrae, Legible Religion, 31.
} 
competing powers within Roman society sought authority. ${ }^{73}$ In an effort to end internal conflict, Numa Pompilius was selected by the members of the elite to become Rome's second king c. 713 BCE. $^{74}$

According to Plutarch, Numa was born in the Sabine city of Cures on the day the city of Rome was founded (April 21, $753 \mathrm{BCE}) .{ }^{75}$ Historical accounts of Numa portray a man dedicated to a life in service of the gods. Livy described him as "a man of renowned justice and piety,"76 and recognized Numa's virtues as having been heavily influenced by the "rigorous and austere discipline of the ancient Sabines." 77 Plutarch further detailed Numa's dedication, describing how "he devoted his hours of privacy and leisure, not to enjoyments and money-making, but to the service of the gods." 78

The Roman belief that Numa lived a simple life, abstaining from an ambition to obtain power or elite status, implied that he had the means for nobility yet made the conscious choice to refrain from luxuries. There is no evidence linking Numa to any political involvement prior to his candidacy for kingship. Romans were thought to have sought someone who had refrained from personal glory to become the successor for Romulus. While the unblemished figure of Numa may or may not have been a romanticization of history, it is clear that Livy and Plutarch made a conscious choice to promote this image. The choice to idealize Numa illuminates how commonly accepted this version of history was for Romans during the eras in which Livy and Plutarch lived. ${ }^{79}$

\footnotetext{
${ }^{73}$ Plut. Numa 2.1-6.

${ }^{74}$ Plut. Numa 5.1; Livy 1.17-18.

${ }^{75}$ Plut. Numa 3.4.

${ }^{76}$ Livy 1.18.

${ }^{77}$ Livy 1.18 .

${ }^{78}$ Plut. Numa 3.6.

${ }^{79}$ Plut. Numa 3.3; Livy 1.18.
} 
Similar to the tales of Romulus, the mythological history of Numa is intertwined with that of the gods. Numa was thought to have been favored and loved by the goddess Egeria, thus spawning an intimate (perhaps even sexual) relationship which bestowed Numa with, "a life of blessedness and a wisdom more than human." ${ }^{80}$ Livy mentions that the merit of this statement was challenged by third century BCE historians as there was no longer unconditional credence that mortals could literally commune with gods. Livy displayed his obvious skepticism to this possibility when stating that Numa "pretended that he had nocturnal interviews with the nymph Egeria." ${ }^{81}$ Plutarch, though more willing to accept when gods might favor a particular individual, agreed that Numa's accounts are "hard to believe." 82

Plutarch claimed that when the Roman aristocracy informed Numa that he was selected to become king, he was quick to decline. ${ }^{83} \mathrm{He}$ explained that Numa's primary point of contention was how his affinity for "peace and quiet [... conflicted with a] government of a city which owed its existence and growth, in a fashion, to war." ${ }^{84}$ Numa's words (according to Plutarch) warned that:

I should therefore become a laughing-stock if I sought to serve the gods, and taught men to honour justice and hate violence and war, in a city which desires a leader of its armies rather than a king. ${ }^{85}$

However, after steady persuasion from his father and close friend Marcius, Numa eventually acquiesced, deciding that this must have been the will of the gods. ${ }^{86}$ Numa's acceptance offered him an opportunity to redirect Rome toward a path of religious reform that embraced "peace and

\footnotetext{
${ }^{80}$ Plut. Numa 4.2.

${ }^{81}$ Livy 1.19.

${ }^{82}$ Plut. Numa 4.3.

${ }^{83}$ Plut. Numa 6.1.

${ }^{84}$ Plut. Numa 5.2.

${ }^{85}$ Plut. Numa 5.5.

${ }^{86}$ Plut. Numa 6.1-7.1.
} 
righteousness" ${ }^{87}$ In contrast to Plutarch's telling, Livy's account makes no mention of any reluctance by Numa to accept the nomination to the throne.

Rome was experiencing internal conflict and civil war between the Romans and the Sabines, and the Latin and Sabine nobility wished to quash civil unrest. ${ }^{88}$ Romans remembered Numa as a man who valued peace over conflict and stood on a platform which promoted religious piety over stratocracy. Livy explained how "Roman senators saw that the balance of power would be on the side of the Sabines" if Numa was named king. However, the Roman aristocracy were desperate to settle on a leader, as there was vulnerability with each day that passed without a secured "head of state." 89 The senate recognized the strength of the Sabines and saw that the quickest method to bridge peace with them was to name a Sabine king.

Characterizing Numa as a man of Sabine decent who expressed no interest in power but was suddenly placed in the highest position of authority creates a palatable history given the geopolitical considerations of the time.

Numa devoted much of his reign to incorporating religious traditions into the daily life of Roman citizens. He saw these traditions as a means to foster a culture which weighed human actions based upon how they might be reflected in the eyes of the gods. ${ }^{90} \mathrm{~A}$ man who lived in accordance to what would be favored by the gods need not live life in fear of hostility. Supporting this viewpoint, Numa's "first measure on assuming the government was to disband the body of three hundred men that Romulus always kept about his person," as he viewed these

\footnotetext{
${ }^{87}$ Plut. Comparison of Lycurgus and Numa 1.4.

${ }^{88}$ Cornell, Beginnings of Rome, 75.

${ }^{89}$ Livy 1.17-18.

${ }^{90}$ Plut. Numa 8.3.
} 
men as a sign of distrust and he wished to instill confidence in Romans that his rule was not built on a platform of fear. ${ }^{91}$

To further promote and celebrate peace, Numa erected the temple of Janus. ${ }^{92}$ When the doors of this temple were open, it signified a time of war or conflict. Conversely, the doors were shut when Rome experienced a time of peace internally and with its bordering nations. ${ }^{93}$ Livy recalled a mere three instances when the doors were shut: once during Numa's reign, a second time after the first Punic war, and a third at the close of the battle of Actium in $31 \mathrm{BCE} .{ }^{94}$ This key detail shows how Numa's memory was aligned with notions of a period of peace and harmony. By erecting a temple that signified peace during his reign, he established a precedent that he was the king who fostered peace, however rare such peace may have turned out to be for later Romans.

Numa formalized Roman religion with the establishment of various religious institutions, rituals, elite religious priesthoods and positions ${ }^{95}$ One example is the order of the Vestal Virgins, who were under the supervision of the pontifex maximus. ${ }^{96}$ The Vestal Virgins were women who were chosen and tasked with maintaining the sacred fire located in the Temple of Vesta. ${ }^{97}$ The Vestals were treated as sacred living symbols of purity. ${ }^{98}$ Livy described another appointment of twelve priests called the Salii to whom Numa gave "the distinctive dress of an embroidered tunic

\footnotetext{
${ }^{91}$ Plut. Numa 7.4.

${ }^{92}$ Livy 1.19; BNP s.v. "Ianus". Janus (Ianus) was the Roman god of passage and his image was often displayed in doorways indicating a transition or transformation of some sort.

${ }^{93}$ Livy 1.19. For more on The Temple of Janus see Green, "Multiple Interpretation of the Opening and Closing of the Temple of Janus: A Misunderstanding of Ovid Fasti 1.281," Mnemosyne 53 (3), 2000, 302-309.

${ }^{94}$ Livy 1.19.

${ }^{95}$ Livy 1.19-20.

${ }^{96}$ Plut. Numa 5.1.

${ }^{97}$ Beard et. al, Religions of Rome, 51.

${ }^{98}$ Livy 1.20.
} 
and over it a brazen cuirass (or armor)." 99 The traditions and responsibilities that came along with these positions fell under Numa's direction.

Most relevant to this thesis, Numa created the position of pontifex maximus and made the first appointment to that role, although there is conflicting evidence about whom exactly he named. Livy asserted that Numa named a senator's son, Numa Marcius, to this position. ${ }^{100}$ Plutarch does not specifically indicate who Numa appointed for this role, yet stated that he "ascribed the institution of that order of the high priests who are called Pontifices, and he himself is said to have been the first among them," which loosely implies that when he established the pontifex maximus, Numa (himself) could have filled that role initially. ${ }^{101}$ Plutarch did reference a father and son, both named Marcius. The son had married Numa's daughter Pompilia, yet Plutarch made no mention of these men holding any office beyond senator. ${ }^{102}$ Marcius senior was said by Plutarch to have been instrumental in persuading Numa to accept becoming king and claimed there was a close family connection between Marcius (the senior) and Numa. ${ }^{103}$ This lack of clarity offers two potential conclusions: either each king took on the mantle of pontifex maximus or the king claimed authority to appoint a new pontifex maximus when necessary.

Regardless of who actually held this position, what is clear is the level of prestige placed upon all of these religious roles. The fate of Rome's well-being fell heavily on the shoulders of those in charge of upholding religious tradition and the pax deorum. Plutarch declared that "the Pontifex Maximus, had the duty of expounding and interpreting divine will," which placed

\footnotetext{
${ }^{99}$ Livy 1.20 .

${ }^{100}$ Livy 1.20.

${ }^{101}$ Plut. Numa 9.1.

102 Plut. Numa 21.1-3.

${ }^{103}$ Plut. Numa 6.1.
} 
immense power and influence on how the will of the gods might be interjected into the affairs of Rome. ${ }^{104}$ Numa took it upon himself to be the educator for new members of these positions. ${ }^{105}$ The history of Numa has identified him as the authority on religious studies, thus his influence was portrayed as having been welcomed with open arms among Romans despite his preconceived worries that he was not the right fit. ${ }^{106}$ These reforms were not depicted as a forced implementation facilitated through the authority of a king, rather they were perceived as part of a process that, according to Plutarch, transformed Rome from "its harsh and warlike temper into one of greater gentleness and justice."107 Livy used words like "uncivilized" and "barbarous people" in his depiction of Romans at the onset of Numa's reign. ${ }^{108}$ He surmised that these characteristics made the people of Rome malleable and receptive to believing Numa's tall tales of direct contact with the gods. Hence, Numa's claim "that he had nocturnal interviews with the nymph Egeria: that it was on her advice that he was instituting the ritual most acceptable to the gods and appointing for each deity his own special priests." ${ }^{109}$ Romans attributed any positive change or development to have been a product of the actions that offered tribute to the very gods which determined their fate and well-being. ${ }^{110}$ Livy declared that Numa's proposed changes and recommendations would "fail to make a deep impression without some claim to supernatural wisdom;" therefore, by positioning himself as a conduit to will of the gods, he was successful in accomplishing his religious agenda. ${ }^{111}$

\footnotetext{
104 Plut. Numa 9.4.

105 Plut. Numa 14.1.

106 Plut. Numa 15.1.

107 Plut. Numa 8.1.

${ }^{108}$ Livy 1.19.

${ }^{109}$ Livy 1.19.

${ }^{110}$ Livy 1.19.

${ }^{111}$ Livy 1.19
} 
Numa was also credited with establishing a precedent for priests to monitor the annual calendar and make any necessary modifications to align the lunar and solar years. He modified the existing calendar to better align the days and months of the year with predictable seasonal changes by adding eleven more days and reorganizing the amount and arrangement of the months. ${ }^{112}$ Periodically throughout the Republic, priests were known to spontaneously insert an extra month to adjust the calendar with the changings of seasons. ${ }^{113}$ Julius Caesar, who was elected to the position of pontifex maximus in $63 \mathrm{BCE}$, took this responsibility very seriously. While simultaneously holding the positions of pontifex maximus and dictator in the early 40s, Caesar utilized this authority to implement major changes to the calendar. With some minor modifications in the $16^{\text {th }}$ century, these changes remain in place today. ${ }^{114}$

Later sources recall no major conflict during the forty-three years of Numa's reign. Rather, the accounts describe Numa's era as a time of peace and happiness for Romans. ${ }^{115}$ Walsh argued that Livy purposefully described Numa and other "great figures of the past in such a way that the reader sees in them the image of Augustus." ${ }^{116}$ One major motivation to have done this was that men like Numa were remembered in history as having caused Rome to be reborn into a time of peace. Augustus was recognized as having propelled Rome into a new era as well and, as previously mentioned, brought about a period of peace, justifying the closing of the doors of the Temple of Janus. By asserting the peaceful nature of Numa's reign, Livy enables his narrative of Augustus as the contemporary embodiment of the more commendable virtues of Rome's past kings. ${ }^{117}$

\footnotetext{
${ }_{112}$ Plut. Numa 18.2-4. These changes were thought to have been inspired by the Egyptian calendar.

${ }^{113}$ Plut. Caes. 59.1.

${ }^{114}$ Plut. Caes. 59.1. Critics of Caesar saw this action not as an execution of his priestly responsibilities, rather as an expression of supreme authority of someone who vied to rule Rome as king.

${ }^{115}$ Livy 1.21; Plut. Numa 22.6-7.

${ }^{116}$ Walsh, Livy, 16.

117 Walsh, Livy, 16.
} 
Numa's religious organizational efforts laid the foundation for institutional priesthoods to endure and to insert themselves into the political affairs of Rome. Roman historians wanted people to recognize that Numa was an active participant in the execution of religious ceremony and set a precedent that these actions coincided with all other responsibilities inherent in a king's role. Romans revered the period of Numa's reign and remained consistent in the way these accounts were told. His reforms established religious institutions that endowed a regal prestige on those appointed to high priest positions. The position given the utmost prestige was the pontifex maximus, who had his own special residence - the domus publica - located on the sacred hill called the Palatine. ${ }^{118}$

The peace experienced during Numa's reign shifted toward war and conquest with his successors. A more militaristic Rome required an evolution in the way religion operated within Roman society. ${ }^{119}$ Livy described how Romans began to feel they had been neglecting to worship the gods properly and this perhaps caused them to remain in ongoing conflict. ${ }^{120}$ Up to this point, religion's role was to provide a sense of peace and connection with the gods.

However, with shifting interests that focused less on the inner workings of a community and more on defense and expansion, the structure of religion lost some of its connectivity to current Roman pursuits.

Livy explained that in the mid-seventh century BCE, war was taking a major toll on Romans. The previous king, Tullus Hostilius, was described to have placed far too little stock in maintaining pax deorum. ${ }^{121}$ Tullus had such a fervent taste for war that he neglected the needs of his soldiers. Soldiers who were prohibited from receiving a respite from the weariness of battle,

\footnotetext{
${ }^{118}$ BNP s.v. "Pontifex, Pontifices".

${ }^{119}$ Livy 1.30-31

${ }^{120}$ Livy 1.31.

${ }^{121}$ Livy 1.31.
} 
which deprived them of opportunities for religious ritual. ${ }^{122}$ Tullus' determination led to his own demise when his health deteriorated, likely from continuing to push his weakened and war-torn body further in battle. Livy explained how it was only then "that he who had once thought nothing less fitting for a king than devotion to sacred things, now suddenly became a prey to every sort of religious terror, and filled the City with religious observances."123 Tullus succumbed to his illness and Ancus Marcius was chosen by the nobility as his successor. ${ }^{124}$ The reign of Ancus (beginning in $642 \mathrm{BCE}$ ) led Rome through the next major developmental stage in Roman religion.

Ancus was believed to have been Numa's grandson, a connection stressed by Livy. This, along with Tullus' de-emphasis of religion and the wartime misfortunes perceived to have been brought on as a result, motivated Ancus to reincorporate religion into all Roman affairs, particularly military campaigns. ${ }^{125}$ Ancus looked first to the pontifex maximus to produce a public facing document outlining the priestly offices Numa had developed. Livy states that, "Numa had instituted religious observances for times of peace, he [Ancus] would hand down the ceremonies appropriate to a state of war." 126 Thus the responsibilities and traditions the pontifex maximus documented addressed ceremonial procedures seeking the blessing of the gods to favor Romans in battle. Religious ritual was now making an appearance in declarations of war, and tribute to the gods were made to promote good favor when engaged in battle. ${ }^{127}$

Ancus instituted the following acts to be executed by the fetials, a college of priests dedicated to Jupiter (subordinate to the flamen who was subordinate to the pontifex maximus):

\footnotetext{
122 Livy 1.29-31.

${ }^{123}$ Livy 1.31.

${ }^{124}$ Livy 1.32 .

${ }^{125}$ Livy 1.32.

${ }^{126}$ Livy 1.32.

${ }^{127}$ Livy 1.32. King Ancus Marcius was credited with incorporating religion deeper into Rome’s military efforts.
} 
The ambassador binds his head in a woolen fillet. When he has reached the frontiers of the nation from whom satisfaction is demanded, he says, "Hear, O Jupiter! Hear, ye confines" - naming the particular nation whose they are - "Hear, O Justice! I am the public herald of the Roman People. Rightly and duly authorized do I come; let confidence be placed in my words." Then he recites the terms of the demands, and calls Jupiter to witness: "If I am demanding the surrender of those men or those goods, contrary to justice and religion, suffer me nevermore to enjoy my native land." He repeats these words as he crosses the frontier, he repeats them to whoever happens to be the first person he meets, he repeats them as he enters the gates and again on entering the forum, with some slight changes in the wording of the formula. If what he demands are not surrendered at the expiration of thirty-three days - for that is the fixed period of grace - he declares war in the following terms: "Hear, O Jupiter, and thou Janus Quirinus, and all ye heavenly gods, and ye, gods of earth and of the lower world, hear me! I call you to witness that this people" - mentioning it by name - "is unjust and does not fulfil its sacred obligations. But about these matters we must consult the elders in our own land in what way we may obtain our rights." 128

The purpose of this elaborate and lengthy ritual was to legitimize the need for war in the eyes of the gods. ${ }^{129}$ This ritual endured long after Ancus, however, Ogilvie claims it evolved from a non-secular process to one managed by the legati (or senate members), the latter version of which is found in accounts of the Second Punic War. ${ }^{130}$

During the remaining years of the post-Numa monarchy, there is no record of specific actions taken by the pontifex maximus or mention of who held the position. The assumption is that this position was held by the reigning king, but sadly there is no evidence to support or dispute that claim. If we believe Livy's account that Numa appointed someone else to the position of pontifex maximus, each king thereafter may have done the same. In the regal period we nevertheless see the establishment of religious structure and institution. Rome developed into a growing power, and Romans now sought the blessings of the gods to maintain their course of expansion. From the creation of

\footnotetext{
${ }^{128}$ Livy 1.32 .

${ }^{129}$ Ogilvie, Livy, 127.

${ }^{130}$ Ogilvie, Livy, 127.
} 
various formal religious posts under Numa to the formalization and expansion of the posts under Ancus, the pontifex maximus became more and more inserted into the affairs of both the community and the military.

\section{b. The Early Republic (509 - Late Third Century BCE)}

The fall of the monarchy left Romans with the task of developing an entirely new form of government. Collaboration over the affairs of Rome was now at the behest of a ruling aristocratic class of elites known as the patricians. ${ }^{131}$ The patricians were born into nobility and constituted Rome's highest social class. Patricians were descendants of the senatorial members during the earliest foundational years under Romulus. ${ }^{132}$ A key feature of the republic was that political power was dispersed through a hierarchy of roles. Some element of high authority over Rome was necessary to maintain order, yet to mitigate any sense of singular authority, the appointment of two co-governing consuls was established. ${ }^{133}$ According to Livy, Romans were determined to prevent indefinite authority from being endowed to an individual, thus "consular authority was limited to one year."134

The well-being of the Roman republic was not solely bound by the confines of political rule; religion also played a key role in the affairs of Roman citizens. The emerging political organizational structures of Rome were formed and initially managed by a group of religiously affiliated officials. Recent analysis by historians views augurs as having played a key role in determining the appropriate physical locations for various civic, religious and political institutions during this time. The augurs' authority also extended to the proceedings of the

\footnotetext{
${ }^{131}$ Livy 2.1.

${ }^{132}$ Livy 1.8. For more on Patricians, see: BNP s.v. "Nobiles".

${ }^{133}$ Cornell, Beginnings of Rome, 226.

${ }^{134}$ Livy 2.1.
} 
senate, which, according to Beard, were "dependent on the correct performance of rituals and on the application of a network of religious rules." 135 Similar to the hierarchy of the governing aristocracy, religious roles were stratified into various priestly colleges.

Among the already established priesthoods, the Romans developed the position of rex sacrorum, the "king for sacrifices." 136 Beard, following Livy, indicated that the founders of the Republic could be perceived to have mildly established some separation between church and state as it pertained (solely) to the rex sacrorum. ${ }^{137}$ Cornell proposed that the use of the Latin rex, meaning king, opened the possibility that the fall of the monarchy did not necessarily dismantle the position of king entirely, but rather de-allocated any governing powers over the political affairs of Rome and left the 'king' with a much more limited authority over religious practice. ${ }^{138}$ Scholars agree that the person appointed to the rex sacrorum was sequestered from political affairs. ${ }^{139}$ To mitigate any concerns that the authority of the 'king of sacrifices' might pose a threat to the Republic, Livy emphasized that "his office was subordinate to the pontifex maximus." ${ }^{140}$ So, despite this new office, the pontifex maximus was still considered the principal bridge between religious and political affairs in the early years of the Republic.

The pontifex maximus was a liaison between organizational worlds and should be viewed as a secretary (or keeper) of religious tradition rather than the architect. ${ }^{141}$ Though he held no authority over any major alterations of religious tradition beyond the process of communication between men and gods, he is described as the most recognized representative of religion in the

\footnotetext{
135 Beard, et. al, Religions of Rome, 23.

${ }^{136}$ Livy 2.2.

${ }^{137}$ Beard et. al, Religions of Rome, 57.

${ }^{138}$ Cornell, Beginnings of Rome, 227.

${ }^{139}$ Cornell, Beginnings of Rome, 226-8; Beard et. al, Religions of Rome, 54-9.

${ }^{140}$ Livy 2.2.

${ }^{141}$ Beard et. al, Religions of Rome, 55.
} 
eyes of both the elite and the common people of Rome. ${ }^{142}$ Livy remarked on the presence of the pontifex maximus at key events witnessed by Roman citizens, such as the dedication of new temples dating all the way back to the regal period. ${ }^{143}$ During the early Republic, the pontifex maximus was looked upon as the expert on religious dictation and acted as consultant for many aspects of public life. He also administered judgement on sacred and civil law, especially during periods of political restructuring. ${ }^{144}$

Sometime around 449 BCE, Livy chronicled the establishment of the decemvirate, a group of 10 patricians tasked with the development and documentation of a set of centralized Roman laws. ${ }^{145}$ According to Cornell, there is widespread controversy among historians as to the validity of Livy's accounts of the exclusion of plebeians (non-Patricians) from political and religious offices. The authority of the decemvirs is also debated. ${ }^{146}$ What is commonly agreed upon is that, while in existence, the decemvirs compiled a set of laws known as the "Twelve Tables," which remained a part of Roman documented law through the duration of the Republic, even though the group of men were forcefully disbanded in 449 BCE. ${ }^{147}$ Livy attributed this disbandment to a plebeian-led uprising that demanded the end of what was perceived as an abuse of unchecked power. ${ }^{148}$

Upon the disbandment of the decemvirs, Livy wrote that it became the responsibility of the pontifex maximus to facilitate an election "to appoint tribunes of the plebs," a process designed to establish more adequate plebeian representation among the aristocracy. ${ }^{149}$ Ogilvie

\footnotetext{
142 Beard et. al, Religions of Rome, 58.

${ }^{143}$ Livy 2.27.

${ }^{144}$ Livy 3.54 ; BNP s.v. "Pontifex, Pontifices".

${ }^{145}$ Livy 3.32 .

${ }^{146}$ Cornell, Beginnings of Rome, 272-292.

${ }^{147}$ Cornell Beginnings of Rome, 272-3.

${ }^{148}$ Livy 3.54.

${ }^{149}$ Livy 3.54.
} 
explained how, prior to the formation of the decemvirs, it would have been unheard of for the pontifex maximus to have presided over tribunal elections. In the time leading up to this election, the pontifex maximus was bound to proceedings that were formalized into the Roman constitution, and the tribunate (the elected representatives of the plebs) was still a semi-informal establishment. ${ }^{150}$ During this time, the position of pontifex maximus was held by one of the two presiding consuls, although the historical record regarding which of the consuls it was is unclear and open to interpretation. ${ }^{151}$ For the sake of analysis, it does not matter which consul was pontifex maximus. Rather, the significance is the content of events being presided over by a man who held both roles. The pontifex maximus, who had previously established a precedent of presiding as judge over sacred law upon the fall of the monarchy, could now be utilized in the essential role of overseer to various political elections that fell under the Roman Constitution. The fact that a consul was also pontifex maximus (which maintained regal prestige) indicates a progression that joined elite political offices with the highest religious office.

Alongside expanding further into the political arena, the role of the pontifex maximus also developed to include more functionary roles during military affairs. Around 437 BCE, Aulus Cornelius Cossus gained fame when, in the heat of battle, he broke through enemy lines and charged the king of Etruria, killing him with a spear to the chest. ${ }^{152}$ Cossus was revered as a hero and celebrated during a victory celebration known as a triumph, where he supposedly

\footnotetext{
${ }^{150}$ Ogilvie, Livy, 494.

${ }^{151}$ Livy 3.54; Ogilvie, Livy, 494-5; Dion. Hal. 5.1.4. Although Livy identified the pontifex maximus in charge of this process as Q. Furius (who was also one of the two consuls, Ogilvie has pointed to conflicting records regarding who in fact was pontifex at this time. There were two consuls, Q. Furius and M. Papirius. Dionysius (a Greek historian alive during the imperial period under the reign of Augustus) mentioned the appointment of Manius Papirius to pontifex maximus by the current pontifices and augurs in 509 BCE. Ogilvie suggests that records may have indicated that a pontifex maximus (who simultaneously held the title of consul) presided over the elections, yet the records neglected to mention a name associated with that role, and that historians (like Dionysius) may have felt a need to assign a name in an attempt to remove further speculation.

${ }^{152}$ Livy 4.19 .
} 
paraded through crowds holding the severed head of the deceased king on the end of his spear, an action in stark contrast with the peace-fostering Numa. ${ }^{153}$ Livy characterized Cossus as "a remarkably handsome man, and equally distinguished for strength and courage."154 Livy admitted controversy over the accuracy of dates associated with titles held by Cossus. For example, in the records of Cossus' spoils in victory (an itemized list of valuables taken from the vanquished by the leader of a victorious army) that were made prior to his war victories as tribune, he is listed as consul. However, other records documented him obtaining his first consulship ten years after his assassination of the Etruscan king. ${ }^{155}$ Despite this lack of clarity, we can determine that, between the timeframe of approximately 425 and 413 BCE, Cossus was elected consul a total of three times. ${ }^{156}$ At some point in the middle of his terms as consul, Cossus was also appointed to the role of pontifex maximus. ${ }^{157}$

Rome was engulfed in wars between the Volscians and Aequi during the first half of fifth century BCE. ${ }^{158}$ As a result, the Romans were often under the military leadership and the authority of a dictator. Cossus's military achievements propelled him to the position of Master of the Horse, making him second-in-command to the dictator Aemilius. ${ }^{159}$ Livy mentioned that the dictator T. Quinctius was advised by Cossus on matters of celebration upon military victories, ${ }^{160}$ and described how Cossus later killed another king in combat, Lars Tolumnius, the king of Veii. ${ }^{161}$ This feat was recounted in a manner that is remarkably similar in detail to the aforementioned king-slaying by Cossus (both portrayed by Livy), welcoming speculation as to

\footnotetext{
${ }^{153}$ Livy 4.20.

${ }^{154}$ Livy 4.19.

155 Livy 4.20.

156 Livy 4.20-50.

${ }^{157}$ Livy 4.27.

158 Recounted in Livy 4.

${ }^{159}$ Livy 4.50.

${ }^{160}$ Livy 4.27.

${ }^{161}$ Livy 4.32.
} 
whether these were in fact two separate occurrences or if the second was a reutterance of the first. Livy followed the description of Cossus' slaying of Tolumnius by mentioning someone being made dictator, but it is unclear if he was referring to Cossus or someone else. ${ }^{162}$

Cossus was a celebrated military commander and was looked upon numerous times to take a leading role as either consul or Master of the Horse throughout his career. He was described by Livy as someone who did not shy away from being recognized for his achievements. It is fair to say that showcasing the head of one's victim is not the act of someone who sought to downplay personal glory. Fortunately for Cossus, there is no evidence to indicate that he faced ridicule for seeking too much admiration. In fact, during the mid-Republic period, seeking glory through success on the battle field had become a typical Roman quality. ${ }^{163}$ Though he was granted great authority over Roman affairs, Livy's accounts portray Cossus as limiting that authority to implementing military strategy rather than seeking further political gain.

Livy's glowing account of the career of Cossus holds significance in that it displayed a leader who was deeply involved in military affairs and likely obtained the title of pontifex maximus as a result. Military achievement and action are proven not to preclude service as pontifex maximus; indeed, it may have benefited Cossus' appointment. After all, anyone so successful in war must have the ear of the gods. Under Cossus, obtaining the office of pontifex maximus now became associated with a man renowned for his military prowess. The previously mentioned pontifex maximus (Furius or Papirius) was also consul, so it is likely that he saw combat as well. However, no evidence in the historical record points to direct military involvement, rather Livy's portrayals of these consuls are more consumed with internal

\footnotetext{
${ }^{162}$ Livy 4.32.

${ }^{163}$ William V. Harris, War and Imperialism in the Republican Rome, 327-70 B.C. (Oxford: Clarendon Press, 1985), 17.
} 
administrative matters. None of these consuls would have been removed from military conflict, as expansion and defense of existing Roman territory remained a steady concern during the Republic period. Additionally, positive public perceptions of an individual grew with displays of gloria. As religion became more and more intertwined with warring pursuits, it stands to reason that gloria would elevate the career path of men seeking both religious and political offices.

During times of war, religious practice and sacred offerings were believed to have aided military victories, which further embedded these traditions into the centralized systems of government. High value was placed on the instruction of the pontifex maximus, as he was now called upon to offer blessings and words of wisdom during times of battle. In one example, Livy describes how Cossus was asked by the consul, Gaius Iulius, to recite in the words of the pontifex maximus to vow to celebrate with competitive sports, known by the Romans as "Great Games" upon victory in an impending battle. ${ }^{164}$ As we can see from this and previous examples, during the era of the Republic, the presence of the pontifex maximus had become desired at the declaration of war, during battle, and during times of celebration for the victories obtained in war.

Cossus's life and career are yet another example of Livy's tendency to romanticize the lives of notable historic figures. He is quick to point out Cossus's handsomeness and likability. Livy described how, during Cossus's career progression, there was significant contention between the tribunes, senate and consuls. ${ }^{165}$ The position of pontifex maximus held appeal to Roman citizens, and obtaining an esteemed religious office had the potential to bridge the divides between these groups. A tribune might question the authority of a consul, but might be more willing to accept the authority of a consul who also held the prestige of being the pontifex

\footnotetext{
${ }^{164}$ Livy 4.27

165 Livy 4.2.
} 
maximus. For example, plebeians accepted the authority of Cossus and his co-consul Medullinus to facilitate an investigation of a plebeian murder, which eased tension between the senate and tribunate. That acceptance may have been influenced more by Cossus' appeal as a religious leader rather than his consulship. ${ }^{166}$ Obtaining the title of pontifex maximus was not always crucial to career progression yet still held prominence in the achievements of a successful elite Roman career. The motivations and career path of men who obtained the title of pontifex maximus was not uniform, rather it depended on the unique circumstances, qualities and goals of the individual.

A moment well known and studied by historians of the Roman Republic is the infamous sacking of Rome by the Gauls that occurred sometime between 390 and 387 BCE. ${ }^{167}$ While Livy's portrayal painted a grim scene of Romans accepting their impending demise, modern scholars like Cornell and Gwynn argue that the extent of damage has been vastly exaggerated and dramatized. ${ }^{168}$ In Livy's version: “The whole country in front and around was now swarming with the enemy, who, being as a nation given to wild outbreaks, had by their hideous howls and discordant clamour filled everything with dreadful noise." 169 The Romans viewed the Gauls as a barbaric society. A chaotic band of men shrieking war cries would most certainly confirm such a stereotype. Livy described the demeanor of many of the Roman soldiers:

They were terrified, and all they thought about was flight, and so utterly had they lost their heads that a far greater number fled to Veii, a hostile city [not Rome], though the Tiber lay in their way, than by the direct road to Rome, to their wives and children. ${ }^{170}$

\footnotetext{
${ }^{166}$ Livy 4.51.

${ }^{167}$ Gwynn, Roman Republic, 14-15.

${ }^{168}$ Gwynn, Roman Republics, 15; Cornell, Beginnings of Rome, 317.

${ }^{169}$ Livy 5.37.

${ }^{170}$ Livy 5.38.
} 
Romans were beginning to see the writing on the walls and had lost sight of the virtues which motivated men to face misfortune head on. With numbers depleted, all hope was lost and the remaining men had no choice but to retreat toward the inner walls of Rome aiming to refortify their position.

As the Gauls descended upon Rome, Livy remarked how the Romans had poured into the city with such haste that the gates were left open. He stated how, "the [Gallic] cavalry, who had ridden on in front, reported that the gates were not shut, there were no pickets on guard in front of them, no troops on the walls." 171 There was no longer any belief that the Romans could effectively defend Rome. Livy described how young able-bodied men, women, children and religious officials:

withdr[ew] into the Citadel and the Capitol, and after getting in stores of arms and provisions, should from that fortified position defend their gods, themselves, and the great name of Rome. The Flamen and priestesses of Vesta were to carry the sacred things of the State far away from the bloodshed and the fire, and their sacred cult should not be abandoned as long as a single person survived to observe it. ${ }^{172}$

The remaining concern was preserving what they deemed most important, their culture and religious integrity. This display by the Romans portrayed how, in their darkest moments, maintaining pax deorum remained at the forefront of a Roman's conscience.

Further portraying an acceptance of defeat, Livy explained how, "the old men returned to their respective homes and, fully prepared to die, awaited the coming of the enemy." "173 Among them were the pontifices under the leadership of the pontifex maximus, M. Fabius (according to Livy), who "recited the solemn formula in which they devoted themselves to death for their

\footnotetext{
${ }^{171}$ Livy 5.39 .

${ }^{172}$ Livy 5.39.

${ }^{173}$ Livy 5.41.
} 
country and the Quirites [citizens of Rome]". ${ }^{174}$ The description of this scene characterizes the principles assumed by those in religious office to stand taller than the soldiers who fled from the enemy, accepting that they most certainly would be slain by the Gauls. There are no direct accounts of who if any of the pontifices or the pontifex maximus may have survived, yet the bulk of Rome is understood to have been burnt to the ground and the Gauls prevented any means of escape. ${ }^{175}$ The manner in which Livy depicted the sacking of Rome leads one to assume that Rome experienced a period of devastation. Cornell explains how the sack of Rome was ultimately not all that crippling to the Romans and, as he says, "was only a momentary setback" which did little to detract from Rome's rising prominence in their pursuit toward provincial growth. ${ }^{176}$ Rome was rebuilt and priorities to strengthen the borders of Rome progressed.

Romans fervently sought to obtain control of the entire Italian peninsula. The Latin War (beginning c. $341 \mathrm{BCE}$ ) became a major step toward achieving that goal. ${ }^{177}$ One of the more notable battles with the Latins c. $340 \mathrm{BCE}$, as mentioned at the beginning of this thesis, discussed a moment where the pontifex maximus was strategically present on the battlefield and called upon to dictate the ritual of devotio. ${ }^{178}$ The exact ritual as presented by Livy goes as follows:

The Pontifex bade him veil his head in his toga praetexta, and rest his hand, covered with the toga, against his chin, then standing upon a spear to say these words: "Janus, Jupiter, Father Mars, Quirinus, Bellona, Lares, ye Novensiles and Indigetes, deities to whom belongs the power over us and over our foes, and ye, too, Divine Manes, I pray to you, I do you reverence, I crave your grace and favour that you will bless the Roman People, the Quirites, with power and victory, and visit the enemies of the Roman People, the Quirites, with fear and dread and death. In like manner as I have uttered this prayer so do I now on behalf of the commonwealth of the Quirites, on behalf of the army, the legions, the auxiliaries

\footnotetext{
${ }^{174}$ Livy 5.41 .

${ }^{175}$ Livy 5.46.

${ }^{176}$ Cornell, Beginnings of Rome, 318.

${ }^{177}$ Livy Book VIII

${ }^{178}$ Livy 8.9. See further, BNP s.v. "devotio".
} 
of the Roman People, the Quirites, devote the legions and auxiliaries of the enemy, together with myself to the Divine Manes and to Earth. ${ }^{179}$

Further rules of the devotio included that if the sacrificial designate survived, an opponent must be chosen for sacrifice and a seven-foot statue must be constructed and buried in the ground. Additionally, if the consul or military leader survived, they were prohibited from performing any further religious rituals again. ${ }^{180}$

The disruption and confusion caused by Decius' sacrifice enabled the Romans to regroup and exploit the chaos to gain advantage and ultimately obtain victory. Whether or not the devotio actually took place is not as important as the fact that the story gained esteem and was remembered by later Romans as a moment where the gods played a crucial role in securing a Roman victory. Furthermore, the pontifex maximus was described as having guided these actions as history has portrayed them. The devotio could be initiated by a consul, dictator or praetor but the sacrifice could be delegated to anyone of his choosing. However, based on this account, the specifics of the ritual and what was to be recited fell to the expertise and religious authority of the pontifex maximus, in order to ensure accurate performance.

The ritual of devotio denotes a moment of transition in the relationship between Romans and the gods where Romans now seek aid rather than peace from the gods. Maintaining pax deorum was becoming a form of payment to obtain the agency of the gods to accomplish victory amid war. During the reign of Numa, ritual extended to maintaining a sense of harmony within a Roman community. With Ancus, ritual began to play a role in the declaration of war and later during the early developments of the Republic, to maintain a spiritual connection with the gods

\footnotetext{
${ }^{179}$ Livy 8.9.

${ }^{180}$ Livy 8.10 .
} 
while in battle hoping to gain good fortune. The gods are now being asked to accept the tribute of sacrifice to then smite the enemy enabling the Romans to overpower their forces.

Around $301 \mathrm{BCE}$, according to Livy, there was growing pressure from the plebeian tribune members, particularly Quintus and Cnaeus Ogulnius, to expand the number of priestly offices of the pontifices and augurs and to open up these positions to plebeians. ${ }^{181}$ Plebeians had already been granted the opportunity to hold elevated political offices, so it was a natural and progressive move to make priestly positions eligible to plebeians as well. ${ }^{182}$ With the support of a plebeian consul named Decius (not the same Decius from the devotio), who argued for these offices, the motion was successfully voted into law and became known as the Lex Ogulnia. ${ }^{183}$ As a result, the pontifices increased from four to eight and the augurs from four to nine. ${ }^{184}$ These accounts show that during this time in history, elite non-patricians first looked for inclusion in affairs through eligibility for political office. However, it became clear that religious office held valuable influence and elevated one's voice in the aristocracy as well. Therefore, plebeians required inclusion in both the political and religious realms in order to achieve adequate integration into Roman affairs.

The pontifex maximus also held the role of liaison between the aristocracy and the common Roman public. In 304 BCE a plebeian, Gnaeus Flavius, was elected to the position of curule aedile, which oversaw the upkeep and management of public works and buildings. ${ }^{185}$ This position was considered a launching point to higher public office. Flavius was the son of a freedman and therefore viewed as lower status than a traditional plebeian by senatorial

\footnotetext{
${ }^{181}$ Livy 10.6.

${ }^{182}$ Livy 10.6.

${ }^{183}$ Livy 10.9 .

${ }^{184}$ Livy 10.9.

${ }^{185}$ Livy 9.46; Cornell, Beginnings of Rome, 263.
} 
nobility. ${ }^{186}$ This sentiment was publicly expressed by members of the senate and caused Flavius to take actions which could be viewed as direct defiance against the elite aristocracy. Livy wrote how Flavius "made public the articles of civil law that had been hidden away in the inner sanctum of the pontiffs" and presented them for public display. ${ }^{187}$ These articles included a calendar which outlined which days legal procedures and events could occur. He used this information as precedent to dedicate the Temple of Concord (named for the Roman goddess Concordia) on the Vulcanal and (with overwhelming support of the general public) requested that the pontifex maximus, Cornelius Barbatus, "recite the usual form of devotion." ${ }^{188}$ Protesting adamantly, Barbatus claimed that only an official of high authority such as consul or dictator had the authority to initiate a dedication of this sort. Nonetheless, due to the staggeringly unanimous will of the people, Barbatus was compelled to oblige the request. ${ }^{189}$ Shortly thereafter, the senate responded by proposing a new law stating that any future dedication required prior senate or tribunal support, negating the authority for an aedile to take such action. ${ }^{190}$ The pontifex maximus is portrayed as having acquiesced to the will of the people, while simultaneously vocalizing his political views that his religious duties should be guided by the will of the nobility. This action indicated a desire for the pontifex maximus to remain a member of the inner circle of the elite nobility. The voice of the masses, however, displayed a level of power that clearly influenced action and (at this time) could force the hand of someone in the highest level of religious office.

\footnotetext{
${ }^{186}$ Livy 9.46.

${ }^{187}$ Livy 9.46.

${ }^{188}$ Livy 9.46.

${ }^{189}$ Livy 9.46.

${ }^{190}$ Livy 9.46.
} 


\section{c. The Second Punic War (218 - 202 BCE)}

There is minimal surviving documented history for the decades leading up to the Second Punic War. Ten of Livy's books on The History of Rome are yet to be discovered or long destroyed. Polybius, whose first book chronicles the events of the First Punic War, makes no notable mention of any major religious activity or reference to the pontifex maximus. There was recurring conflict between Carthage and Rome since the beginning of the First Punic War in 264 BCE. ${ }^{191}$ That war lasted over two decades and left Carthage in a sorry state of affairs. As the Carthaginians began to restrengthen themselves, they sought expansion in the territory of Spain. Gwynn attributed much of Rome's victory in the First Punic War to the strength of their allies, so the conflict in Spain drew the attention of Rome and ultimately began the Second Punic War. ${ }^{192}$ Over the course of this war, the Carthaginian general Hannibal proved to be a strategic adversary who won many battles and threatened Rome's ability to withstand the destruction brought on by ever-increasing loss. ${ }^{193}$

As Livy discussed the second dictatorship of Quintus Fabius Maximus (217 BCE), he pointed out that the dictator claimed the misfortunes of battle to a "neglect of the auspices and [... ] religious duties [... rather than] bad generalship." 194 The solution involved seeking the direction of pontifex maximus L. Cornelius Lentulus to reestablish the pax deorum. Following the advice of Lentulus, the praetor (named M. Aemilius) implored the people of Rome to offer a portion of their spring yields toward a tremendous feast called a lectisternium that would be facilitated and overseen by the "ten keepers of the Sacred Books." 195 The ceremonies culminated

\footnotetext{
${ }^{191}$ Gwynn, Roman Republic, 49.

192 Gwynn, Roman Republic, 51-3.

${ }^{193}$ Livy 22.9.

${ }^{194}$ Livy 22.9.

195 Livy 22.10.
} 
with a "vowing of temples" to Venus (goddess of balance) and Mens (goddess of mindfulness) that was designed to bring an equilibrium between the gods and Romans. ${ }^{196}$ The motivations for this offering raises an important question: Were Romans still seeking to obtain a harmonious peace with the gods? Seeking the aid of the gods was steadily becoming common practice. Romans now proactively sought aid in war with the ceremony of lectisternium. Rituals and offerings further solidified the expectation that the gods were not just pseudo-participants but had the ability to become active ones.

The pontifex maximus continued to be viewed in the eyes of Romans not only as integral to their well-being in their day to day lives, but also the figurehead whose blessings and ritual instruction were the determining factor in gaining the support of the gods in times of war. The position had remained a respected role and typically one that was granted after years of religious dedication. However, in 212 BCE, Livy noted that the election of Publius Licinius Crassus Dives as pontifex maximus was unorthodox because of his age and lack of experience. The Romans had experienced tremendous loss over the course of the Second Punic War. As a result, the aristocracy was severely depleted, creating an immediate necessity to appoint droves of men to political and religious office. ${ }^{197}$ Livy specified how "the consuls found the levying of troops a difficult task, for there were not sufficient men of the required age to answer both purposes," meaning that Crassus' good fortune was also buoyed by a lack of available candidates. ${ }^{198}$ Crassus had not properly followed the progression of religious office holdings, yet was promoted to this office during a time of war. Romans were depicted to have sought out Crassus primarily

\footnotetext{
${ }^{196}$ Livy 22.10.

${ }^{197}$ Livy 25.1-5.

${ }^{198}$ Livy 25.5.
} 
based on a combination of his gravitas (a quality of one who carried themselves with dignity and importance) and gloria. ${ }^{199}$ Livy described Crassus as:

Not only a fine soldier but he was in every respect one of the most accomplished citizens of the time; he combined in himself all the advantages which nature and fortune could bestow; he was an exceptionally handsome man and possessed remarkable physical strength; he was considered a most eloquent speaker, whether he was pleading a cause or defending or attacking a measure in the senate or before the Assembly, and he was thoroughly conversant with pontifical law. ${ }^{200}$

This list of characteristics emphasizes why a man lacking in political or religious tenure could rise to more elevated positions in a far quicker manner than the bulk of his peers. Livy stated that Crassus was also elected censor without following the standard path of escalating political positions: "Crassus had not been either consul or praetor before he was made censor, he went straight from the aedileship to the censorship."201

Crassus' actions as pontifex maximus were described in much greater detail by Livy than any of Crassus' predecessors. Crassus was portrayed as having strategically used the influence obtained by being the pontifex maximus to execute his will. He successfully pressured C. Valerius Flaccus, who was otherwise viewed dishonorably, to redeem himself by taking on the responsibilities of the Flamen of Jupiter. ${ }^{202}$ This act displayed the sway afforded to the pontifex maximus, especially when coupled with the charm of a highly revered man of the people.

Flaccus' religious appointment also facilitated his placement in the senate $(209 \mathrm{BCE}) .{ }^{203}$ These expanding political connections may have elevated Crassus' political leverage.

\footnotetext{
${ }^{199}$ Livy 25.5.

${ }^{200}$ Livy 30.1.

${ }^{201}$ Livy 27.6.

${ }^{202}$ Livy 27.7-8.

${ }^{203}$ Livy 27.8. According to Livy, there was an ancient custom which granted the Flamens a seat in the senate, yet the privilege had not been utilized in generations until Flaccus.
} 
Crassus continued to advance his political career, becoming praetor sometime following the appointment of Flaccus in 209 BCE. ${ }^{204}$ In 205 BCE, well over a decade into the Second Punic War, Crassus was elected consul. ${ }^{205}$ Livy chose to emphasize the title of pontifex maximus each time he chronicled a newly elected political office obtained by Crassus. ${ }^{206}$ For example, when Livy referenced the naming of titles such as of Master of the Horse (appointed by the Dictator Fulvius), censor, praetor, and consul, Livy would state, "P. Licinius Crassus, the pontifex maximus, was named ..."207 By doing so, Livy implied that Crassus' appointment to the position of pontifex maximus held significance as he progressed in his involvement in Roman affairs.

Livy portrayed Crassus as having been the epitome of the virtuous Roman. He displayed the priestly qualities that were elevated by the religious reforms of Numa while simultaneously holding the mantle of an esteemed war hero in the image of Romulus. Plutarch claimed that the dictator, Fabius Maximus, favored Crassus to represent Rome against Hannibal over his fellow co-consul, P. Cornelius Scipio. ${ }^{208}$ Fabius thought Scipio had ambition to obtain too much authority over Roman affairs. Despite pressure from Fabius to serve as an alternative to Scipio, Crassus declined to lead legions into Africa. Plutarch described Crassus's response to have come from his character, "which was not contentious, but gentle," and would not elicit unnecessary conflict with Scipio. ${ }^{209}$ To avoid debate, Crassus explained that it was his duty as pontifex maximus to remain close to Rome, and campaigned primarily in the closer military theater of Bruttium. ${ }^{210}$ Plutarch's depiction of this reaction portrayed Crassus's level of control of his

\footnotetext{
${ }^{204}$ Livy 27.22 .

${ }^{205}$ Livy 28.38 .

${ }^{206}$ Livy 25.5-22.

${ }^{207}$ Livy 27.5-22

${ }^{208}$ Plut. Fab. Max. 25.4.

${ }^{209}$ Plut. Fab. Max. 25.4.

${ }^{210}$ Plut. Fab. Max. 25.5, 28.44.
} 
ambitions and care not to exceed more than what was appropriate, as well as his commitment to his religious obligations. Livy clearly admired Crassus and his depictions were complimentary, yet he did not specifically reference this event in the same manner. Livy recounted a series of speeches between Fabius and Scipio and ultimately stated that Scipio advanced to Africa. ${ }^{211}$ There was no direct account of Crassus being asked by Fabius to defy Scipio, which calls into question Crassus' actual role in Fabius’ push to hinder Scipio’s ambitions.

Polybius, whose works cover the Second Punic War (with substantial portions lost, destroyed or undiscovered), makes no mention of Crassus or any name similar to his. He does, however, chronicle the life of Scipio in similar form to Livy's portrayal of Crassus. Literary flattery seems to have been common practice for historians during the time periods of Livy, Plutarch, and Polybius.

\footnotetext{
${ }^{211}$ Livy 28.45-6. In one of Scipio's speeches, Livy claimed how he does mention Crassus's duties as pontifex maximus and how that should prevent him from venturing too far from Rome, which suggests the concern may have been subtly acknowledged.
} 


\section{Conclusion}

Early in the Roman monarchy, religion was used by Romulus to facilitate violence and domination. Romulus' successor Numa repurposed religion to unite a small yet divided city-state at a time when war was supposedly removed from the forefront of Roman concerns. Rome was in its infancy of societal development and what was needed most was a collective sense of unity and identity. Religion served as a means to unite its citizens for a common purpose. As Romans embarked into more routine conflict with their neighboring city-states, the resulting expansion required religion to adapt beyond a construct that catered to peace and to extended into the facets of war.

As this analysis has shown, religion was profoundly intertwined in the sociopolitical affairs of Rome from its foundational beginnings and on through the Republican period. For much of the period under study, our surviving ancient accounts can only depict what later Romans perceived to have been the history of their ancestors. There remains an abundance of archeological evidence but only minimal fragmentary written accounts of Roman history composed by historians earlier than the first century BCE. The lack of surviving records leaves modern historians with an inability to adequately piece together the earliest moments of Roman history without the works of men like Livy, Plutarch and Polybius. We must contextualize these sources to determine influences that may have skewed how various events have been portrayed. The foundations of religion and the pontifex maximus developed in conjunction with the development of the Republic. As the priorities of the Romans evolved, the characteristics of who best fit the mold of the pontifex maximus, and the duties of that position, adapted to ensure that a fruitful relationship with the gods was maintained. 
Even though their opinions varied, Livy, Plutarch, and Polybius saw religion as playing an integral role in the development of Roman society. The portrayals of Romulus and Numa include a mythology that placed a high value on seeking an interpretation of the gods to guide the decisions of the state. Romulus justified his ascension to rule an emerging city-state through the will of the gods and Numa forged and utilized religious piety to unify a divided populace. The organization of religious colleges, offices and leadership roles such as pontifex maximus established a precedent, and religion remained a fixed aspect of Roman pursuits both internally and externally. As the Republic developed, the Roman leadership invoked the qualities of a Numa-like figure to mitigate individualist desires through fostering piousness, yet equally demanded the unstoppable and dominating militaristic qualities of a Romulan leader to lead Romans toward a partnership with the gods that granted victory in all pursuits.

We have seen moments of sociopolitical progression of religious practices and institutions both at the onset of the established Republic and their continued development through the end of the Second Punic War. It is also quite clear that religious practices and institutions like the pontifex maximus developed and changed over time. Not only did religious institutions continue, the appointed religious officials grew in numbers and progressively incorporated plebeians into the newly available offices. The pontifex maximus continued to preside over political and religious elections and also became a fixture of military support both on the battlefield and in rituals seeking military victory.

Livy's historical objectives and literary style can be viewed as an example of a contemporary religious enthusiast, demonstrated by his portrayals of an increased presence of Roman priests being incorporated into war campaigns and senatorial 
proceedings over time. Livy and Plutarch imparted their accounts through the lens of their own personal religious beliefs, and thus chose to accentuate and propagate their accounts to justify their own logical or desired conclusions. The historical context of their environment indicated that religious prominence endured and that its relevance continued to spread beyond the central communities of Rome and into military affairs outside the borders of Roman territories.

The establishment of priestly colleges such as the pontifices, flamines, augurs, fetials, and Vestals defined obligations designed to preserve the well-being of the Roman public. These processes should be seen as proof that the Romans formally institutionalized religious traditions that upheld and preserved sacred law. ${ }^{212}$ Further, as it pertained to war, members of these priestly colleges - such as the fetials - were incorporated into ritual specific to the declaration of war. The pontifex maximus was regularly called upon to ensure there was support and favor from the gods to boost morale and strengthen military forces. The ultimate goal was to appease the gods to the point of granting victory and ideally instill fear among Roman enemies. This morphed from seeking favor from the gods to a request for direct intervention.

The pontifex maximus became so deeply incorporated into Roman affairs that the position became integral to the political career progression of many notable Romans mentioned in this analysis. Additionally, the pontifex maximus evolved into a key element which aided in military processes and the justification of both victories and loss. A victory meant that the proper ritual and traditions had been properly executed and observed. A loss indicated that there was a failure to properly appease the gods and

\footnotetext{
${ }^{212}$ Rives, Religion in Rome, 83; Champion, Peace of the Gods, 7.
} 
maintain good favor. Maintaining the pax deorum, which once equated to the well-being of Rome and its citizens, had now taken on a modified meaning that led to the belief that it was not necessarily the peace of the gods Rome desired, but the aid of the gods to propel Rome to greater prominence and glory. 


\section{Bibliography}

Primary

Dionysius of Halicarnassus. Roman Antiquities. Translated by Earnest Cary. Loeb Classical Library. Cambridge: Harvard University Press, 1978.

https://penelope.uchicago.edu/Thayer/e/roman/texts/dionysius_of_halicarnassus/home.ht

$\underline{\mathrm{ml}}$

Livy, Titus. Livy: The Rise of Rome: Books 1-5. Translated by T. J. Luce. Oxford: Oxford University Press, 1998.

Livy: Rome's Italian Wars: Books 6-10. Translated by J. C. Yardley. Oxford: Oxford University Press, 2013.

. Livy: Hannibal's War: Books 21-30. Translated by J. C. Yardley. Oxford: Oxford University Press, 2006.

- Livy's The History of Rome: Vol. 1-3. Translated by Rev. Canon Roberts. Edited by Ernest Rhys. J. M. Dent \& Sons, Ltd., London, 1905 http://mcadams.posc.mu.edu/txt/ah/Livy/

Plutarch. Comparison of Lycurgus and Numa. Translated by Bernadotte Perrin. Loeb Classical Library. Cambridge: Harvard University Press, 1923. https://penelope.uchicago.edu/Thayer/E/Roman/Texts/Plutarch/Lives/home.html

—. Life of Caesar. Translated by Bernadotte Perrin. Loeb Classical Library. Cambridge: Harvard University Press, 1923. https://penelope.uchicago.edu/Thayer/E/Roman/Texts/Plutarch/Lives/home.html 
- Life of Fabius Maximus (Cunctator). Translated by Bernadotte Perrin. Loeb Classical Library. Cambridge: Harvard University Press, 1923. https://penelope.uchicago.edu/Thayer/E/Roman/Texts/Plutarch/Lives/home.html

—. Life of Numa. Translated by Bernadotte Perrin. Loeb Classical Library. Cambridge: Harvard University Press, 1923. https://penelope.uchicago.edu/Thayer/E/Roman/Texts/Plutarch/Lives/home.html

Polybius. Histories - Book 6. Translated by H. J. Edwards. Loeb Classical Library. Cambridge: Harvard University Press, 1978. https://penelope.uchicago.edu/Thayer/E/Roman/Texts/Polybius/

Secondary

Beard, Mary; James North, and Simon Price. Religions of Rome: Volume I. A History. Cambridge: Cambridge University Press, 2013.

Cancik, Hubert and Helmuth Schneider. Brill's New Pauly $2^{\text {nd }}$ ed., Leiden: Brill, 2007.

Champion, Craig B. The Peace of the Gods: Elite Religious Practices in the Middle Roman Republic. Princeton: Princeton University Press, 2017.

Cornell, T. J. The Beginnings of Rome: Italy and Rome from the Bronze Age to the Punic Wars (c. 1000-264 BC). New York: Routledge, 1995.

Flower, Harriet. Roman Republics. New Jersey: Princeton University Press, 2010.

Gagarin, Michael. The Oxford Encyclopedia of Ancient Greece and Rome. Oxford: Oxford University Press, 2010.

Glinister, Fay. "Politics, Power, and the Divine: The Rex Sacrorum and the Transition from Monarchy to Republic at Rome.” Antichthon: Journal of the Australian Society for 
Classical Studies; Adelaide, Vol. 51 (2017): 59-76.

http://dx.doi.org.proxy.lib.pdx.edu/10.1017/ann.2017.6

Green, S. J. "Multiple interpretations of the opening and closing of the temple of Janus: a misunderstanding of Ovid 'Fasti' 1.281.” Mnemosyne 53 (June, 2000): 302. https://www.jstor.org/stable/4433099

Gwynn, David M. The Roman Republic: A Very Short Introduction. Oxford: Oxford University Press, 2012.

Harris, William V. War and Imperialism in the Republican Rome, 327-70 B.C. New York: Oxford Clarendon Press, 1985.

Hornblower, Simon, Antony Spawforth and Esther Eidinow. Oxford Classical Dictionary, $4^{\text {th }}$ ed. Oxford: Oxford University Press, 1998.

Lendon, J. E. "Histories without history: Against Roman historiography." The Cambridge Companion to The Roman Historians, edited by Andrew Feldherr, 41-62. Cambridge: Cambridge University Press, 2009.

Macrae, Duncan. Legible Religion: Books, Gods, and Rituals in Roman Culture. Cambridge: Harvard University Press, 2016.

Mellor, Ronald. The Historians of Ancient Rome: An Anthology of the Major Writings. $3^{\text {rd }}$ ed. New York: Routledge, 2013.

Ogilvie, R. M. A Commentary on Livy: Books 1-5. Oxford: Oxford University Press, 1984.

Orlin, Eric M. Temples, Religion, and Politics in the Roman Republic. Leiden: Brill, 2002.

Redford, Donald B. The Oxford Encyclopedia of Ancient Egypt. Oxford: Oxford University Press, 2005.

Rives, James. Religion in the Roman Empire. Blackwell Publishing, 2007. 
Satterfield, Susan. "Livy and the Pax Deum." Classical Philology 111, no. 2 (April 2016): 16576. https://doi-org.proxy.lib.pdx.edu/10.1086/686236

Walsh, P. G. Livy: His Historical Aims \& Methods. Cambridge: Cambridge University Press, 1961.

Whitmarsh, Tim. Beyond the Second Sophistic: Adventures in Greek Post-Classicism. Berkeley: University of California Press, 2018. 